\title{
MICROBIAL IMMOBILIZATION AND THE RETENTION OF ANTHROPOGENIC NITRATE IN A NORTHERN HARDWOOD FOREST
}

\author{
Gregory P. Zogg, ${ }^{1,3}$ Donald R. Zak, ${ }^{1}$ Kurt S. Pregitzer, ${ }^{2}$ And Andrew J. Burton ${ }^{2}$ \\ ${ }^{1}$ School of Natural Resources and Environment, University of Michigan, Ann Arbor, Michigan 48109-1115 USA \\ ${ }^{2}$ School of Forestry and Wood Products, Michigan Technological University, Houghton, Michigan 49931 USA
}

Abstract. To determine the importance of microorganisms in regulating the retention of anthropogenic $\mathrm{NO}_{3}^{-}$, we followed the belowground fate and flow of ${ }^{15} \mathrm{NO}_{3}{ }^{-}$in a mature northern hardwood forest, dominated by Acer saccharum Marsh. Total recovery of added ${ }^{15} \mathrm{~N}\left(29.5 \mathrm{mg}{ }^{15} \mathrm{~N} / \mathrm{m}^{2}\right.$ as $\left.\mathrm{NaNO}_{3}\right)$ in inorganic $\mathrm{N}$, microbial immobilization in forest floor and soil microbial biomass, soil organic matter, and root biomass pools $(0-10 \mathrm{~cm}$ depth) was $93 \%$ two hours following application of the ${ }^{15} \mathrm{NO}_{3}{ }^{-}$but rapidly dropped to $\sim 29 \%$ within one month, presumably due to movement of the isotope into other plant tissues or deeper into soil. Microbial immobilization was initially (i.e., at $2 \mathrm{~h}$ ) the largest sink for ${ }^{15} \mathrm{NO}_{3}{ }^{-}$ ( $21 \%$ in forest floor; $16 \%$ in soil microbial biomass). After one month, total ${ }^{15} \mathrm{~N}$ recovery varied little (24-18\%) throughout the remainder of the growing season, suggesting that the major $\mathrm{N}$ transfers among pools occurred relatively rapidly. At the end of the four-month experiment, the main fates of the ${ }^{15} \mathrm{~N}$ label were in soil organic matter (7\%), root biomass $(6 \%)$, and $\mathrm{N}$ immobilized in forest floor and soil microbial biomass $(6 \%)$.

Temporal changes in the ${ }^{15} \mathrm{~N}$ enrichment (atom $\%$ excess ${ }^{15} \mathrm{~N}$ ) of plant and soil pools during the first month of the experiment indicated the dynamic nature of $\mathrm{NO}_{3}{ }^{-}$cycling in this forest. The ${ }^{15} \mathrm{~N}$ enrichment of soil microbial biomass and the forest floor significantly increased two hours after isotope additions, suggesting rapid microbial immobilization of $\mathrm{NO}_{3}{ }^{-}$. In contrast, the ${ }^{15} \mathrm{~N}$ enrichment of soil organic matter did not peak until day 1 , presumably because much of the added ${ }^{15} \mathrm{~N}$ cycled through microorganisms before becoming stabilized in soil organic matter, or it directly entered soil organic matter via physical processes. Furthermore, the ${ }^{15} \mathrm{~N}$ enrichment of root biomass $(<0.5-\mathrm{mm}$ diameter and $0.5-$ $2.0 \mathrm{~mm}$ diameter) was greatest between day 7 and day 28 , following significant increases in the ${ }^{15} \mathrm{~N}$ enrichment of soil organic matter (day 1) and, more importantly, $\mathrm{NH}_{4}{ }^{+}$(day 2). From these data we conclude that microorganisms are immediate, short-term sinks for anthropogenic $\mathrm{NO}_{3}{ }^{-}$. Although the long-term fate of $\mathrm{NO}_{3}{ }^{-}$additions to this forest is likely in soil organic matter and plants, the cycling of $\mathrm{N}$ through microorganisms appears to be the major short-term factor influencing patterns of $\mathrm{NO}_{3}{ }^{-}$retention in this ecosystem.

Key words: belowground fate and flow of nitrate; microbial immobilization; nitrate, anthropogenic; nitrate retention and microbial pathways; nitrogen deposition; nitrogen saturation; plant and microbial competition for nitrogen; sugar maple (Acer saccharum).

\section{INTRODUCTION}

Human activities have significantly altered the global nitrogen (N) cycle (Vitousek et al. 1997), resulting in unprecedented rates of atmospheric $\mathrm{N}$ deposition in forests throughout the northeastern United States and Europe (Lovett and Kinsam 1990, Shannon and Sisterson 1992, Ollinger et al. 1993). Anthropogenic N additions in excess of biotic demand, particularly as $\mathrm{NO}_{3}$, can have negative effects on the functioning of both terrestrial and aquatic ecosystems (i.e., N saturation, sensu Ågren and Bosatta 1988, Aber et al. 1989, Aber 1992). For example, $\mathrm{NO}_{3}{ }^{-}$leaching can cause soil acidification and the export of nutrient cations, potentially leading to declines in forest growth (Johnson et

Manuscript received 25 May 1998; revised 10 March 1999; accepted 10 May 1999; final version received 24 June 1999.

${ }^{3}$ Present address: Department of Life Sciences, University of New England, Biddeford, Maine 04005 USA.

E-mail: gzogg@mailbox.une.edu al. 1991, Aber 1992). Nitrate also is a major contributor to the eutrophication and acidification of associated groundwater, streams, and lakes (Aber et al. 1989, Driscoll and VanDresen 1993). Because the growth of most northern temperate trees appears to be $\mathrm{N}$ limited, plants are thought to be important sinks for anthropogenic $\mathrm{NO}_{3}{ }^{-}$and may slow or halt the deleterious effects of $\mathrm{N}$ deposition (Aber et al. 1989, Rastetter et al. 1991). However, microbial assimilation of $\mathrm{NO}_{3}{ }^{-}$also may be a critical pathway for the retention of anthropogenic $\mathrm{NO}_{3}{ }^{-}$(Zak et al. 1990, Davidson et al. 1992, Stark and Hart 1997).

Microorganisms could influence the fate and flow of anthropogenic $\mathrm{NO}_{3}{ }^{-}$additions directly through the accumulation of $\mathrm{N}$ in their biomass and indirectly via the cycling of $\mathrm{NO}_{3}{ }^{-}$through microbial cells. Numerous studies have demonstrated a high capacity for $\mathrm{NO}_{3}{ }^{-}$ uptake by soil microorganisms (Jackson et al. 1989, Schimel and Firestone 1989, Zak et al. 1990, Davidson 
et al. 1992, Stark and Hart 1997), presenting the possibility that the initial, short-term fate of anthropogenic $\mathrm{NO}_{3}{ }^{-}$may be in microbial biomass. However, retention of $\mathrm{N}$ in live, microbial biomass could only be an important, long-term sink for $\mathrm{NO}_{3}{ }^{-}$if microbial biomass is accruing. Thus, it is unlikely to be a major factor in late-successional forests in which annual increases in microbial biomass are small (Holmes and Zak 1994, Stark and Hart 1997).

In mature northern hardwood forests, the initial flow of anthropogenic $\mathrm{NO}_{3}{ }^{-}$through microbial cells, and its subsequent incorporation into soil organic matter or uptake by plants, may be an important mechanism of $\mathrm{N}$ retention. Previous work indicates that Acer saccharum Marsh. (sugar maple), a dominant overstory tree in this ecosystem, appears to have a limited capacity for $\mathrm{NO}_{3}{ }^{-}$uptake and satisfies much of its $\mathrm{N}$ requirements through $\mathrm{NH}_{4}{ }^{+}$assimilation (Rothstein et al 1996). Given that microorganisms in these forests can rapidly assimilate $\mathrm{NO}_{3}{ }^{-}$(Zak et al. 1990), microbes could potentially out-compete the dominant overstory trees for $\mathrm{NO}_{3}{ }^{-}$. Upon death of microbial cells, $\mathrm{N}$ previously assimilated as $\mathrm{NO}_{3}^{-}$could enter soil organic matter or be released as $\mathrm{NH}_{4}{ }^{+}$into soil solution. Thus, the cycling of $\mathrm{N}$ through microorganisms could facilitate the retention of anthropogenic $\mathrm{NO}_{3}{ }^{-}$by increasing rates of $\mathrm{N}$ incorporation into soil organic matter or by increasing the availability of $\mathrm{NH}_{4}^{+}$, which is preferentially used by sugar maple. Our objective was to determine the importance of microbial immobilization as a pathway for anthropogenic $\mathrm{NO}_{3}{ }^{-}$retention in northern hardwood forests. To accomplish this, we followed the belowground fate and flow of ${ }^{15} \mathrm{NO}_{3}^{-}$ throughout a single growing season in a sugar-mapledominated forest in northern Lower Michigan.

\section{Methods \\ Study site}

Our study was conducted in a northern hardwood forest in northern Lower Michigan, USA $\left(45^{\circ} 33^{\prime} \mathrm{N}\right.$, $84^{\circ} 51^{\prime} \mathrm{W}$ ). The stand is $\sim 84 \mathrm{yr}$ of age and is dominated by Acer saccharum Marsh. (basal area relative dominance $=87 \%$ ). The Typic Haplorthod soil is sandy $(89.4 \%)$ and low in organic C $(1.7 \%)$. Mean annual precipitation is $830 \mathrm{~mm}$, and mean annual air temperature is $5.2^{\circ} \mathrm{C}$ (NOAA 1983). Net $\mathrm{N}$ mineralization for the May-November growing season (0-10 cm depth) is $\sim 68 \mathrm{~kg} \mathrm{~N} / \mathrm{ha}$ (calculated from Zogg et al. 1996), and annual wet-plus-dry $\mathrm{N}$ deposition is $\sim 9 \mathrm{~kg} \mathrm{~N} / \mathrm{ha}(65 \%$ as $\mathrm{NO}_{3}{ }^{-} \mathrm{N}$; MacDonald et al. 1992). More detailed floristic, edaphic, and climatic data for the stand are reported elsewhere (Site 3 in Pregitzer et al. 1992, MacDonald et al. 1991, and MacDonald et al. 1992).

\section{${ }^{15} \mathrm{NO}_{3}{ }^{-}$addition and field sampling}

Three $9-\mathrm{m}^{2}$ plots were established within $100 \mathrm{~m}$ of one another in early June 1997. We systematically ap- plied $29.5 \mathrm{mg}{ }^{15} \mathrm{~N} / \mathrm{m}^{2}$ to each plot as a single addition of ${ }^{15} \mathrm{~N}$-enriched $\mathrm{Na}^{15} \mathrm{NO}_{3}(99.9 \%)$ dissolved in $\mathrm{H}_{2} \mathrm{O}(4$ $\mathrm{L} / \mathrm{m}^{2}$ ). The amount of $\mathrm{NO}_{3}{ }^{-}-\mathrm{N}$ added to each plot was similar to that entering the soil from a major rain event. Forest floor and belowground plant, microbial, and soil pools were sampled one day prior to application of the ${ }^{15} \mathrm{NO}_{3}{ }^{-}$and at periodic intervals throughout the growing season (i.e., 2 h, 8 h, 1 d, 2 d, 1 wk, 2 wk, 4 wk, 6 wk, $8 \mathrm{wk}, 11 \mathrm{wk}$, and $16 \mathrm{wk}$ following ${ }^{15} \mathrm{NO}_{3}{ }^{-}$additions). On each sampling date, surface litter (i.e., the forest floor, Oi horizon) was collected from three random $10 \times 20 \mathrm{~cm}$ locations within each $9-\mathrm{m}^{2}$ plot. Following forest-floor collection, two soil samples were excavated (from beneath each forest-floor sample) with a polyvinyl chloride corer (5.4-cm inner diameter, 10$\mathrm{cm}$ depth) and composited; soil samples consisted of both organic (Oe/Oa, 1-3 cm thick) and mineral horizons (A + E, 7-9 cm thick). Soil cores were placed on ice and transported to our laboratory at the University of Michigan Biological Station, allowing us to begin processing samples within $0.5 \mathrm{~h}$ of field collection.

\section{Laboratory analyses}

Forest-floor samples were dried at $70^{\circ} \mathrm{C}$ for $48 \mathrm{~h}$, ground with a Wiley mill, and passed through a $2-\mathrm{mm}-$ mesh sieve. Live, non-woody roots $(<2.0 \mathrm{~mm}$ in $\mathrm{di}-$ ameter) were systematically removed from the soil samples by hand and rinsed free of soil and organic matter with deionized water. The roots were separated by diameter class (very fine roots, $<0.5 \mathrm{~mm}$ diameter; fine roots, $0.5-2.0 \mathrm{~mm}$ diameter), dried at $70^{\circ} \mathrm{C}$ for 48 $\mathrm{h}$, and ground with a mortar and pestle. The $\mathrm{N}$ concentration (in milligrams $\mathrm{N}$ per gram) and percentage ${ }^{15} \mathrm{~N}$ of the forest floor, very fine roots, and fine roots were determined by mass spectrometry (Integra CN Carbon and Nitrogen Isotope Analyzer [Europa Scientific, Vandalia, Ohio, USA]).

Soil $\mathrm{NH}_{4}{ }^{+}-\mathrm{N}$ and $\mathrm{NO}_{3}{ }^{-}-\mathrm{N}$ were determined by extracting $15 \mathrm{~g}$ of soil with $25 \mathrm{~mL}$ of a $2 \mathrm{~mol} / \mathrm{L}$ solution of $\mathrm{KCl}$; the extract was subsequently stored at $5^{\circ} \mathrm{C}$ for colorimetric determination of $\mathrm{NH}_{4}{ }^{+}$and $\mathrm{NO}_{3}{ }^{-}$(Alpkem 300 Rapid Flow Analyzer [Alpkem Corporation, Wilsonville, Oregon, USA]). Chloroform-labile microbial biomass $\mathrm{N}$ (hereafter referred to as "soil microbial biomass") was determined using a direct-extraction procedure (Brookes et al. 1985); $15 \mathrm{~g}$ of soil was immediately extracted with $50 \mathrm{~mL}$ of $0.5 \mathrm{~mol} / \mathrm{L} \mathrm{K}_{2} \mathrm{SO}_{4}$ and a second 15-g subsample was similarly extracted after $6 \mathrm{~d}$ of $\mathrm{CHCl}_{2}$ fumigation. $\mathrm{K}_{2} \mathrm{SO}_{4}$ extracts were frozen, digested, and later analyzed colorimetrically for $\mathrm{NH}_{4}{ }^{+}$. Isotope in the $\mathrm{NH}_{4}{ }^{+}-\mathrm{N}, \mathrm{NO}_{3}{ }^{-}-\mathrm{N}$, and microbial-N extracts was collected by diffusion (Brooks et al. 1989) and percentage ${ }^{15} \mathrm{~N}$ determined by mass spectrometry. The remaining bulk soil was air-dried, ground in a roller mill, and stored for determination of $\mathrm{N}$ concentration and percentage ${ }^{15} \mathrm{~N}$ by mass spectrometry; an additional 
15-g subsample was used to determine oven-dry masses $\left(105^{\circ} \mathrm{C}\right.$ for $\left.48 \mathrm{~h}\right)$.

\section{Calculations and statistical analyses}

On each sample date, the added ${ }^{15} \mathrm{~N}$ recovered in forest floor, very fine roots, fine roots, and extractable $\mathrm{NH}_{4}{ }^{+}$and $\mathrm{NO}_{3}{ }^{-}\left(\mathrm{mg}{ }^{15} \mathrm{~N} / \mathrm{m}^{2}\right)$ was determined by multiplying the $\mathrm{N}$ concentration of the pool (in milligrams $\mathrm{N}$ per gram) by the mass of the component (in grams per square centimeter; e.g., mass of the forest floor or mass of soil to a depth of $10 \mathrm{~cm}$ ) and its atom $\%$ excess ${ }^{15} \mathrm{~N}$ (i.e., measured percentage of ${ }^{15} \mathrm{~N}$ minus natural abundance of ${ }^{15} \mathrm{~N}$ ). The ${ }^{15} \mathrm{~N}$ recovered in soil microbial biomass was calculated as the difference in the ${ }^{15} \mathrm{~N}$ recovered in non-fumigated and fumigated soil samples; we did not use a correction factor in our estimate of microbial ${ }^{15} \mathrm{~N}$. The ${ }^{15} \mathrm{~N}$ recovered in soil organic matter was calculated as the difference between the ${ }^{15} \mathrm{~N}$ recovered in bulk soil and the ${ }^{15} \mathrm{~N}$ recovered in soil microbial biomass and extractable inorganic $\mathrm{N}\left(\mathrm{NH}_{4}{ }^{+}\right.$ and $\mathrm{NO}_{3}{ }^{-}$). Recovery of added ${ }^{15} \mathrm{~N}$ is expressed on an areal basis (in milligrams ${ }^{15} \mathrm{~N}$ per square meter) and as a percentage of the total added label $\left(29.5 \mathrm{mg}{ }^{15} \mathrm{~N} / \mathrm{m}^{2}\right)$.

The percentage ${ }^{15} \mathrm{~N}$ of soil microbial biomass was calculated as the difference in the total ${ }^{15} \mathrm{~N}$ content (in milligrams ${ }^{15} \mathrm{~N}$ per square meter) between non-fumigated and fumigated extracts, divided by the difference in $\mathrm{N}$ content (in milligrams $\mathrm{N}$ per square meter) between non-fumigated and fumigated extracts; no correction factor was used. The percentage ${ }^{15} \mathrm{~N}$ of soil organic matter was computed in a similar manner: the total ${ }^{15} \mathrm{~N}$ content of soil organic matter (milligrams ${ }^{15} \mathrm{~N}$ per square meter in bulk soil minus the ${ }^{15} \mathrm{~N}$ in soil microbial biomass and extractable inorganic-N pools) was divided by the $\mathrm{N}$ content of soil organic matter (milligrams $\mathrm{N}$ per square meter in bulk soil minus the $\mathrm{N}$ in soil microbial biomass and extractable inorganic$\mathrm{N}$ pools).

For a given pool, differences in mean $\mathrm{N}$ concentration, percentage ${ }^{15} \mathrm{~N}$, and atom $\%$ excess ${ }^{15} \mathrm{~N}$ among sample dates were compared using one-way analyses of variance (ANOVA) and Fisher's least significant difference (LSD) procedures. Differences in the mean recovery of added ${ }^{15} \mathrm{~N}$ among pools and sample dates were compared using a two-way ANOVA and Fishers LSD procedure. Significance for all statistical analyses was accepted at $\alpha=0.05$; tests were performed using the SYSTAT software package (Wilkinson 1993).

\section{RESULTS}

Total recovery of ${ }^{15} \mathrm{~N}$ was $93 \% 2 \mathrm{~h}$ after $\mathrm{NO}_{3}{ }^{-}$application, but recovery rapidly dropped to $\sim 29 \%$ within 1 mo (Fig. 1). After $1 \mathrm{mo},{ }^{15} \mathrm{~N}$ recovery varied little throughout the remainder of the experiment (24 to $18 \%$ ). Only $28 \%$ of the label was recovered as inorganic $\mathrm{N}$ (exclusively as $\mathrm{NO}_{3}^{-}$) at $2 \mathrm{~h}$, and recovery of ${ }^{15} \mathrm{~N}$ in the inorganic $\mathrm{N}$ pool was $<1 \%$ after $2 \mathrm{wk}$. Four months after addition of the isotope, the largest sinks for ${ }^{15} \mathrm{~N}$ were soil organic matter (7\% of added label, Fig. 1), root biomass (6\% of added label), and $\mathrm{N}$ immobilized in soil microbial biomass and the forest floor (6\% of added label).

During the first $28 \mathrm{~d}$ of the experiment, when most major changes in ${ }^{15} \mathrm{~N}$ recovery occurred, the $\mathrm{N}$ concentration (milligrams $\mathrm{N}$ per gram) of plant and soil pools remained relatively constant. There were no significant differences $(P<0.05$, ANOVA) among sample dates in the $\mathrm{N}$ concentration of any measured pool, except for $\mathrm{NO}_{3}{ }^{-}$which increased immediately following addition of the ${ }^{15} \mathrm{NO}_{3}{ }^{-}$(Table 1 ). However, extractable $\mathrm{NO}_{3}{ }^{-}-\mathrm{N}$ returned to pre-isotope addition levels after $2 \mathrm{~d}$. In contrast, there was considerable temporal variability in the percentage ${ }^{15} \mathrm{~N}$ of a given pool (Table 2 ). The percentage ${ }^{15} \mathrm{~N}$ of forest floor and $\mathrm{NO}_{3}{ }^{-}$significantly increased (relative to natural abundance levels) within $2 \mathrm{~h}$ of ${ }^{15} \mathrm{NO}_{3}{ }^{-}$additions and remained elevated for $14 \mathrm{~d}$. The percentage ${ }^{15} \mathrm{~N}$ of soil microbial biomass also was significantly higher than the natural abundance $2 \mathrm{~h}$ following ${ }^{15} \mathrm{NO}_{3}{ }^{-}$additions, but returned to background levels within $8 \mathrm{~h}$. The percentage ${ }^{15} \mathrm{~N}$ of soil organic matter, very fine roots, and fine roots increased significantly after $1 \mathrm{~d}$ and remained consistently high thereafter.

Two hours after isotope addition, the fate of ${ }^{15} \mathrm{~N}$ was in $\mathrm{NO}_{3}{ }^{-}\left(8.4 \pm 1.1 \mathrm{mg}{ }^{15} \mathrm{~N} / \mathrm{m}^{2}\right.$; mean $\left.\pm 1 \mathrm{SE}\right)$, soil organic matter $\left(8.2 \pm 3.6 \mathrm{mg}{ }^{15} \mathrm{~N} / \mathrm{m}^{2}\right)$, forest floor $(6.1$ $\left.\pm 0.4 \mathrm{mg}{ }^{15} \mathrm{~N} / \mathrm{m}^{2}\right)$, and soil microbial biomass (4.6 \pm $2.7 \mathrm{mg}{ }^{15} \mathrm{~N} / \mathrm{m}^{2}$ ) (Fig. 2A). After $28 \mathrm{~d}$ the added ${ }^{15} \mathrm{~N}$ was entirely absent from the $\mathrm{NO}_{3}{ }^{-}$pool, had declined significantly in soil organic matter $\left(3.3 \pm 0.6 \mathrm{mg}{ }^{15} \mathrm{~N} / \mathrm{m}^{2}\right)$ and the forest floor $\left(1.9 \pm 0.3 \mathrm{mg}{ }^{15} \mathrm{~N} / \mathrm{m}^{2}\right)$, and had almost completely disappeared from soil microbial biomass $\left(0.4 \pm 0.1 \mathrm{mg}{ }^{15} \mathrm{~N} / \mathrm{m}^{2}\right.$; Fig. 2A). Although almost no ${ }^{15} \mathrm{~N}$ was recovered in root biomass within $2 \mathrm{~h}$, roots were significant sinks for ${ }^{15} \mathrm{~N}$ by day 1 (very fine roots, $2.0 \pm 0.8 \mathrm{mg}{ }^{15} \mathrm{~N} / \mathrm{m}^{2}$; fine roots, $0.3 \pm 0.1 \mathrm{mg}{ }^{15} \mathrm{~N} / \mathrm{m}^{2}$ ). In addition, we recovered small but detectable amounts of ${ }^{15} \mathrm{~N}$ as $\mathrm{NH}_{4}{ }^{+}$between day 1 and day 14 . Forest floor and soil microbial biomass were significantly greater sinks for ${ }^{15} \mathrm{~N}$ than were fine roots or very fine roots during the first $2 \mathrm{~d}$ of the experiment; after $2 \mathrm{~d}$ there were no significant differences in ${ }^{15} \mathrm{~N}$ recovery among root and microbial pools.

Given that there were no significant differences in the $\mathrm{N}$ concentration of a given pool among sample dates (with the exception of $\mathrm{NO}_{3}^{-}$), we used the appearance of the ${ }^{15} \mathrm{~N}$ in the various pools (atom $\%$ excess ${ }^{15} \mathrm{~N}$ ) to track the flow of the $\mathrm{NO}_{3}{ }^{-}$among them (Fig. 2B). The ${ }^{15} \mathrm{~N}$ enrichment of forest floor and soil microbial biomass reached their maximal levels simultaneously with $\mathrm{NO}_{3}{ }^{-}$, significantly increasing the atom $\%$ excess ${ }^{15} \mathrm{~N}$ $2 \mathrm{~h}$ after addition of ${ }^{15} \mathrm{NO}_{3}{ }^{-}$(Table 2, Fig. 2B). The atom $\%$ excess ${ }^{15} \mathrm{~N}$ of soil organic matter did not peak until day 1 , followed by $\mathrm{NH}_{4}{ }^{+}-\mathrm{N}$ at day 2 , and subsequently fine root and very fine root biomass on days 7-28 (Table 2, Fig. 2B). 


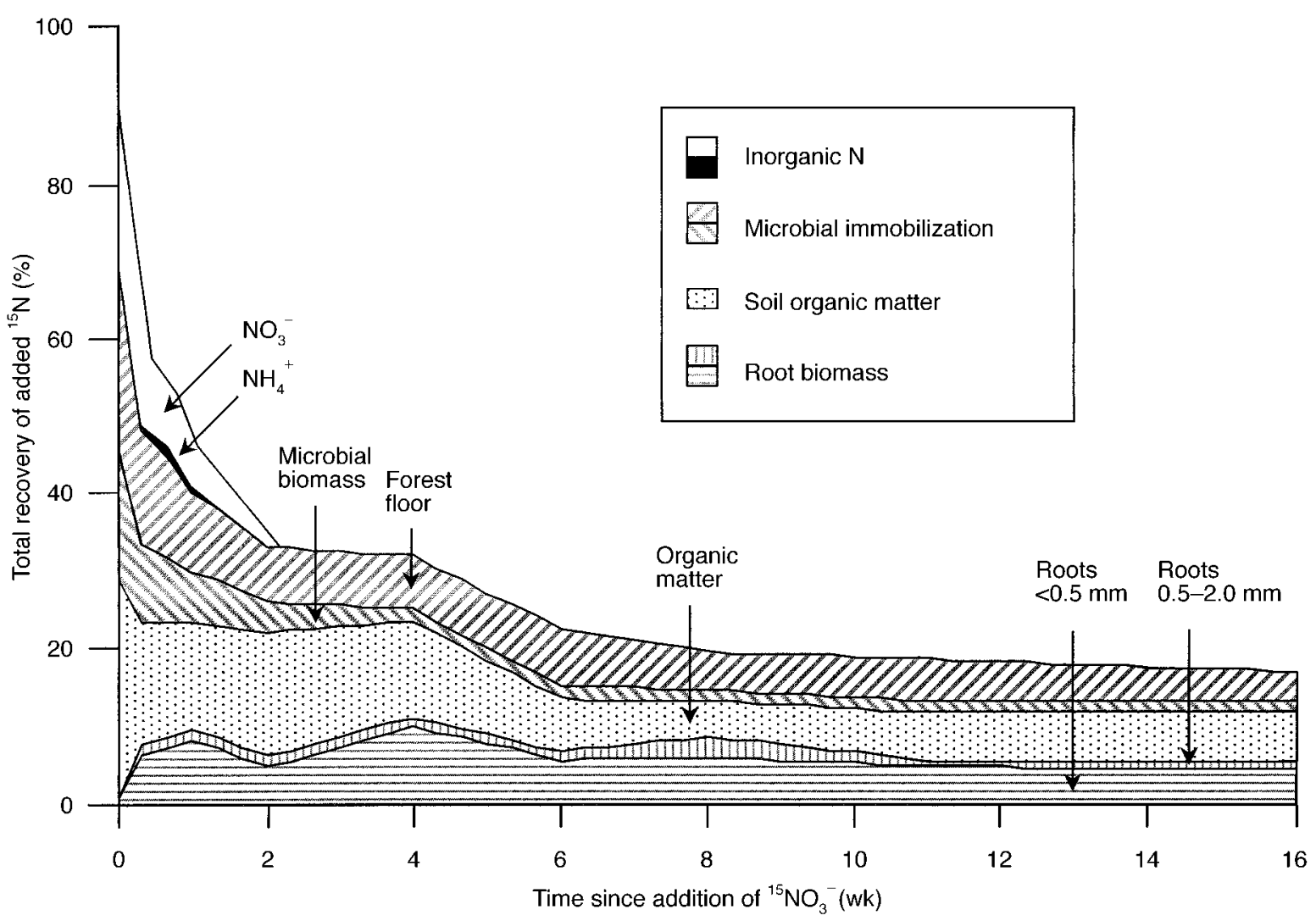

FIG. 1. Total recovery of added ${ }^{15} \mathrm{NO}_{3}{ }^{-}$in inorganic-N, microbial, soil-organic-matter, and root-biomass pools, throughout the four-month growing season. See Methods: Calculations and statistical analysis for description of calculations.

\section{DISCUSSION}

Fate of ${ }^{15} \mathrm{NO}_{3}^{-}$

Microbial immobilization was the greatest sink for ${ }^{15} \mathrm{NO}_{3}{ }^{-}$immediately following isotope addition (i.e., at $2 \mathrm{~h}$ ). Assuming that ${ }^{15} \mathrm{~N}$ recovered in the forest floor was assimilated by microorganisms, we estimate that more than one third of the ${ }^{15} \mathrm{NO}_{3}{ }^{-}$was initially consumed by microbial immobilization $(21 \%$ in forest floor, $16 \%$ in soil microbial biomass). Immobilization into soil microbial biomass could actually be much greater, because we did not use a correction factor in our calculation of biomass and the ${ }^{15} \mathrm{~N}$ contained in this pool. If we had used a correction factor of 0.68 , as recommended by Brookes et al. (1985), this would have resulted in a $47 \%$ increase in the amount of isotope contained in soil microbial biomass. Nonetheless, our conservative estimates of microbial immobilization are consistent with reports from several other studies in which soil microorganisms assimilated $30-50 \%$ of added ${ }^{15} \mathrm{NO}_{3}{ }^{-}$after $2 \mathrm{~d}$ (Jackson et al. 1989, Schimel and Firestone 1989, Zak et al. 1990, Norton and Firestone 1996), and indicate that microorganisms were the largest initial sink for added $\mathrm{NO}_{3}{ }^{-}$.

Soil organic matter also was a major sink for ${ }^{15} \mathrm{NO}_{3}{ }^{-}$. Two hours following the addition of ${ }^{15} \mathrm{NO}_{3}{ }^{-}, \sim 28 \%$ of the label was recovered in soil organic matter. Movement of ${ }^{15} \mathrm{NO}_{3}{ }^{-}$into soil organic matter was likely facilitated by the turnover of microbial cells (see Flow of ${ }^{15} \mathrm{NO}_{3}{ }^{-}$, below), but it is also possible that other mechanisms may be responsible for the incorporation of ${ }^{15} \mathrm{~N}$ into soil organic matter. For example, Davidson et al. (1991) have argued that the almost immediate disappearance of ${ }^{15} \mathrm{~N}$ from inorganic $\mathrm{N}$ pools, characteristic of pool-dilution studies, resulted from physical processes in soil; they suggested that $\sim 10 \%$ of the ${ }^{15} \mathrm{NO}_{3}{ }^{-}$added in their study was incorporated into soil organic matter via an undescribed abiological process. The rapid incorporation of ${ }^{15} \mathrm{~N}$ into non-microbial, recalcitrant pools also has been reported by others (e.g., Vitousek and Matson 1985, Strickland et al. 1992). We concur with those who suggest that abiotic mechanisms of $\mathrm{N}$ incorporation into soil organic matter could be an important process influencing ecosystem $\mathrm{N}$ retention (Johnson 1992, Magill et al. 1997). However, this remains a poorly understood process.

The total amount of ${ }^{15} \mathrm{~N}$ recovered in plant, microbial, and soil pools was initially high (i.e., $93 \%$ at 2 h). After 4 mo, however, we recovered a much smaller amount of the added label (i.e., 18\%). Possible mechanisms of ${ }^{15} \mathrm{~N}$ loss throughout the course of the experiment include denitrification, leaching into deeper soil 
TABLE 1. Mass and nitrogen concentrations for inorganic-N, microbial, soil-organic-matter, and root-biomass pools during the first $28 \mathrm{~d}$ of the experiment. Data are means with $1 \mathrm{SE}$ in parentheses.

\begin{tabular}{|c|c|c|c|c|c|c|c|c|c|}
\hline \multirow[b]{3}{*}{ Pool } & \multirow{3}{*}{$\begin{array}{l}\text { Mass } \\
\left(\mathrm{g} / \mathrm{cm}^{2}\right)\end{array}$} & \multicolumn{8}{|c|}{$\mathrm{N}$ concentration $(\mathrm{mgN} / \mathrm{g}) \dagger$} \\
\hline & & \multirow[b]{2}{*}{ Initial } & \multicolumn{7}{|c|}{ Time since addition of ${ }^{15} \mathrm{~N}(\mathrm{~d})$} \\
\hline & & & 0.08 & 0.33 & 1 & 2 & 7 & 14 & 28 \\
\hline \multicolumn{10}{|l|}{ Inorganic $\mathrm{N}$} \\
\hline $\mathrm{NO}_{3}{ }^{-}-\mathrm{N}$ & $8.243 \S$ & $\begin{array}{r}0.0013 \\
(0.0001)\end{array}$ & $\begin{array}{r}0.0016 \\
(0.0003)\end{array}$ & $\begin{array}{c}0.0021 * \\
(0.0004)\end{array}$ & $\begin{array}{r}0.0012 \\
(0.0001)\end{array}$ & $\begin{array}{c}0.0011 \\
(0.0002)\end{array}$ & $\begin{array}{c}0.0015 \\
(0.0003)\end{array}$ & $\begin{array}{r}0.0013 \\
(0.0004)\end{array}$ & $\begin{array}{r}0.0008 \\
(0.0003)\end{array}$ \\
\hline $\mathrm{NH}_{4}^{+}-\mathrm{N}$ & $8.243 \S$ & $\begin{array}{r}0.0018 \\
(0.0006)\end{array}$ & $\begin{array}{r}0.0012 \\
(0.0004)\end{array}$ & $\begin{array}{r}0.0016 \\
(0.0005)\end{array}$ & $\begin{array}{c}0.0011 \\
(0.0002)\end{array}$ & $\begin{array}{r}0.0016 \\
(0.0010)\end{array}$ & $\begin{array}{r}0.0027 \\
(0.0013)\end{array}$ & $\begin{array}{r}0.0012 \\
(0.0003)\end{array}$ & $\begin{array}{r}0.0008 \\
(0.0001)\end{array}$ \\
\hline \multicolumn{10}{|l|}{ Microbial immobilization } \\
\hline Forest floor & $\begin{array}{r}0.0712 \| \\
(0.0023)\end{array}$ & $\begin{array}{l}18.7305 \\
(0.7390)\end{array}$ & $\begin{array}{l}17.7764 \\
(0.5762)\end{array}$ & $\begin{array}{l}17.6477 \\
(0.8298)\end{array}$ & $\begin{array}{l}18.2595 \\
(0.7226)\end{array}$ & $\begin{array}{l}19.4186 \\
(0.5185)\end{array}$ & $\begin{array}{l}18.9544 \\
(1.2508)\end{array}$ & $\begin{array}{l}19.1151 \\
(1.0908)\end{array}$ & $\begin{array}{l}19.9228 \\
(1.0558)\end{array}$ \\
\hline Soil microbial biomass & $8.243 \S$ & $\begin{array}{r}0.0619 \\
(0.0242)\end{array}$ & $\begin{array}{r}0.0709 \\
(0.0195)\end{array}$ & $\begin{array}{r}0.0714 \\
(0.0157)\end{array}$ & $\begin{array}{r}0.0857 \\
(0.0251)\end{array}$ & $\begin{array}{r}0.0617 \\
(0.0049)\end{array}$ & $\begin{array}{r}0.0748 \\
(0.0089)\end{array}$ & $\begin{array}{r}0.0631 \\
(0.0148)\end{array}$ & $\begin{array}{r}0.0573 \\
(0.0122)\end{array}$ \\
\hline Soil organic matter & $8.243 \S$ & $\begin{array}{r}0.9287 \\
(0.1372)\end{array}$ & $\begin{array}{r}1.2023 \\
(0.0877)\end{array}$ & $\begin{array}{r}1.3699 \\
(0.0648)\end{array}$ & $\begin{array}{r}0.9638 \\
(0.0513)\end{array}$ & $\begin{array}{r}1.0065 \\
(0.0640)\end{array}$ & $\begin{array}{r}1.0757 \\
(0.0855)\end{array}$ & $\begin{array}{r}1.4370 \\
(0.2960)\end{array}$ & $\begin{array}{r}1.0895 \\
(0.3048)\end{array}$ \\
\hline \multicolumn{10}{|l|}{ Roots } \\
\hline $\begin{array}{l}\text { Very fine roots } \\
(<0.5-\mathrm{mm} \text { diameter })\end{array}$ & $\begin{array}{l}0.0106 \mathbb{I} \\
(0.0003)\end{array}$ & $\begin{array}{l}18.0671 \\
(0.3997)\end{array}$ & $\begin{array}{l}16.8574 \\
(0.5995)\end{array}$ & $\begin{array}{l}17.1970 \\
(0.3330)\end{array}$ & $\begin{array}{l}17.2138 \\
(0.2725)\end{array}$ & $\begin{array}{l}16.8731 \\
(0.2581)\end{array}$ & $\begin{array}{l}16.4128 \\
(0.7068)\end{array}$ & $\begin{array}{l}17.6838 \\
(0.5477)\end{array}$ & $\begin{array}{l}18.5000 \\
(0.5680)\end{array}$ \\
\hline $\begin{array}{l}\text { Fine roots } \\
\quad(0.5-2.0-\mathrm{mm} \text { diameter })\end{array}$ & $\begin{array}{l}0.0053 \mathbb{1} \\
(0.0005)\end{array}$ & $\begin{array}{r}8.2823 \\
(0.4870)\end{array}$ & $\begin{array}{r}9.4937 \\
(0.3326)\end{array}$ & $\begin{array}{r}9.8854 \\
(0.6547)\end{array}$ & $\begin{array}{l}11.1334 \\
(0.9771)\end{array}$ & $\begin{array}{r}9.4423 \\
(0.5801)\end{array}$ & $\begin{array}{r}9.7557 \\
(0.6066)\end{array}$ & $\begin{array}{r}9.7474 \\
(0.3152)\end{array}$ & $\begin{array}{r}9.8850 \\
(0.9994)\end{array}$ \\
\hline
\end{tabular}

$\dagger \mathrm{N}$ concentrations are the mean of three samples. For each pool, concentrations marked with an asterisk $(*)$ differ significantly from initial values $(P<0.05$, ANOVA).

\$ Mass values were determined by averaging samples across the first month of the experiment (three plots for each of the eight dates shown at right). There were no significant differences in mass for forest floor or root biomass pools during the first $28 \mathrm{~d}$ of the experiment $(P<0.05$, ANOVA; data not shown).

$\S$ The mass for soil pools is the bulk density to a depth of $10 \mathrm{~cm}$ (i.e., bulk density in $\mathrm{g} / \mathrm{cm}^{3}$ multiplied by $10 \mathrm{~cm}$ ). Value was determined at the start of the experiment and assumed to be unchanging throughout the growing season; thus, no standard error of the mean across sample dates is given.

The mass for the forest floor pool is the mass of surface litter.

II The mass for below ground plant pools is the standing crop of roots to a depth of $10 \mathrm{~cm}$.

horizons, and transport into other above- and belowground plant tissues. Although we did not measure denitrification, the amount of $\mathrm{N}$ lost through this process is low in the well-drained, sandy upland soil of this northern hardwood ecosystem (Merrill and Zak 1992) and thus likely represented a minor loss of ${ }^{15} \mathrm{~N}$ during our experiment. Declines in ${ }^{15} \mathrm{~N}$ recovery are more likely the result of leaching and plant uptake. Added ${ }^{15} \mathrm{~N}$

TABLE 2. Percentage ${ }^{15} \mathrm{~N}$ of inorganic-N, microbial, soil-organic-matter and root-biomass pools during the first $28 \mathrm{~d}$ of the experiment. Values are the means of three samples, with 1 SE in parentheses.

\begin{tabular}{|c|c|c|c|c|c|c|c|c|}
\hline \multirow[b]{2}{*}{ Pool } & \multirow{2}{*}{$\begin{array}{c}\text { Natural } \\
\text { abundance }\end{array}$} & \multicolumn{7}{|c|}{ Time since addition of ${ }^{15} \mathrm{~N}(\mathrm{~d})$} \\
\hline & & 0.08 & 0.33 & 1 & 2 & 7 & 14 & 28 \\
\hline \multicolumn{9}{|l|}{ Inorganic $\mathrm{N}$} \\
\hline $\mathrm{NO}_{3}{ }^{-}-\mathrm{N}$ & $\begin{array}{c}0.3684 \\
(0.0007)\end{array}$ & $\begin{array}{c}7.0121 * \\
(0.4326)\end{array}$ & $\begin{array}{c}5.7019 * \\
(0.9362)\end{array}$ & $\begin{array}{c}4.5886 * \\
(1.8280)\end{array}$ & $\begin{array}{c}3.1512 * \\
(0.9218)\end{array}$ & $\begin{array}{l}1.5088^{*} \\
(0.4255)\end{array}$ & $\begin{array}{c}0.4981 \\
(0.0349)\end{array}$ & $\begin{array}{c}0.4062 \\
(0.0053)\end{array}$ \\
\hline $\mathrm{NH}_{4}{ }^{+}-\mathrm{N}$ & $\begin{array}{c}0.3680 \\
(0.0008)\end{array}$ & $\begin{array}{c}0.3881 \\
(0.0020)\end{array}$ & $\begin{array}{c}0.4101 \\
(0.0118)\end{array}$ & $\begin{array}{c}0.4862 * \\
(0.0265)\end{array}$ & $\begin{array}{c}0.5175^{*} \\
(0.0243)\end{array}$ & $\begin{array}{c}0.4555^{*} \\
(0.0061)\end{array}$ & $\begin{array}{c}0.4233 \\
(0.0205)\end{array}$ & $\begin{array}{c}0.3963 \\
(0.0092)\end{array}$ \\
\hline \multicolumn{9}{|l|}{ Microbial immobilization } \\
\hline Forest floor & $\begin{array}{c}0.3657 \\
(0.0001)\end{array}$ & $\begin{array}{c}0.4031 * \\
(0.0027)\end{array}$ & $\begin{array}{c}0.4012 * \\
(0.0018)\end{array}$ & $\begin{array}{c}0.3991 * \\
(0.0008)\end{array}$ & $\begin{array}{c}0.3971 * \\
(0.0041)\end{array}$ & $\begin{array}{c}0.3852 * \\
(0.0031)\end{array}$ & $\begin{array}{c}0.3794 \\
(0.0045)\end{array}$ & $\begin{array}{c}0.3875 \\
(0.0007)\end{array}$ \\
\hline Soil microbial biomass & $\begin{array}{c}0.3721 \\
(0.0093)\end{array}$ & $\begin{array}{c}0.4430 * \\
(0.0157)\end{array}$ & $\begin{array}{c}0.3907 \\
(0.0070)\end{array}$ & $\begin{array}{c}0.3840 \\
(0.0316)\end{array}$ & $\begin{array}{c}0.3848 \\
(0.0078)\end{array}$ & $\begin{array}{c}0.3779 \\
(0.0145)\end{array}$ & $\begin{array}{c}0.3746 \\
(0.0023)\end{array}$ & $\begin{array}{c}0.3721 \\
(0.0027)\end{array}$ \\
\hline Soil organic matter & $\begin{array}{c}0.3670 \\
(0.0005)\end{array}$ & $\begin{array}{c}0.3693 \\
(0.0061)\end{array}$ & $\begin{array}{c}0.3688 \\
(0.0018)\end{array}$ & $\begin{array}{c}0.3727 * \\
(0.0025)\end{array}$ & $\begin{array}{c}0.3725^{*} \\
(0.0024)\end{array}$ & $\begin{array}{c}0.3713 * \\
(0.0019)\end{array}$ & $\begin{array}{c}0.3705^{*} \\
(0.0010)\end{array}$ & $\begin{array}{c}0.3712 * \\
(0.0012)\end{array}$ \\
\hline \multicolumn{9}{|l|}{ Roots } \\
\hline Very fine roots $(<0.5-\mathrm{mm})$ & $\begin{array}{l}0.3669 \\
(0.001)\end{array}$ & $\begin{array}{c}0.3789 \\
(0.0028)\end{array}$ & $\begin{array}{c}0.4086 \\
(0.0069)\end{array}$ & $\begin{array}{c}0.4627 * \\
(0.0411)\end{array}$ & $\begin{array}{c}0.4676^{*} \\
(0.0488)\end{array}$ & $\begin{array}{c}0.4937^{*} \\
(0.0243)\end{array}$ & $\begin{array}{c}0.4487 * \\
(0.0353)\end{array}$ & $\begin{array}{c}0.5123^{*} \\
(0.0487)\end{array}$ \\
\hline Fine roots $(0.5-2.0-\mathrm{mm})$ & $\begin{array}{c}0.3669 \\
(0.0001)\end{array}$ & $\begin{array}{c}0.3699 \\
(0.0004)\end{array}$ & $\begin{array}{c}0.3875 \\
(0.0032)\end{array}$ & $\begin{array}{c}0.4139 * \\
(0.0055)\end{array}$ & $\begin{array}{c}0.4223^{*} \\
(0.0091)\end{array}$ & $\begin{array}{c}0.4531 * \\
(0.0172)\end{array}$ & $\begin{array}{c}0.4215^{*} \\
(0.0189)\end{array}$ & $\begin{array}{r}0.4380^{*} \\
(0.0146)\end{array}$ \\
\hline
\end{tabular}

Note: For each pool, atom percentage ${ }^{15} \mathrm{~N}$ values marked with an asterisk (*) differ significantly from natural abundance levels $(P<0.05$, ANOVA $)$. 

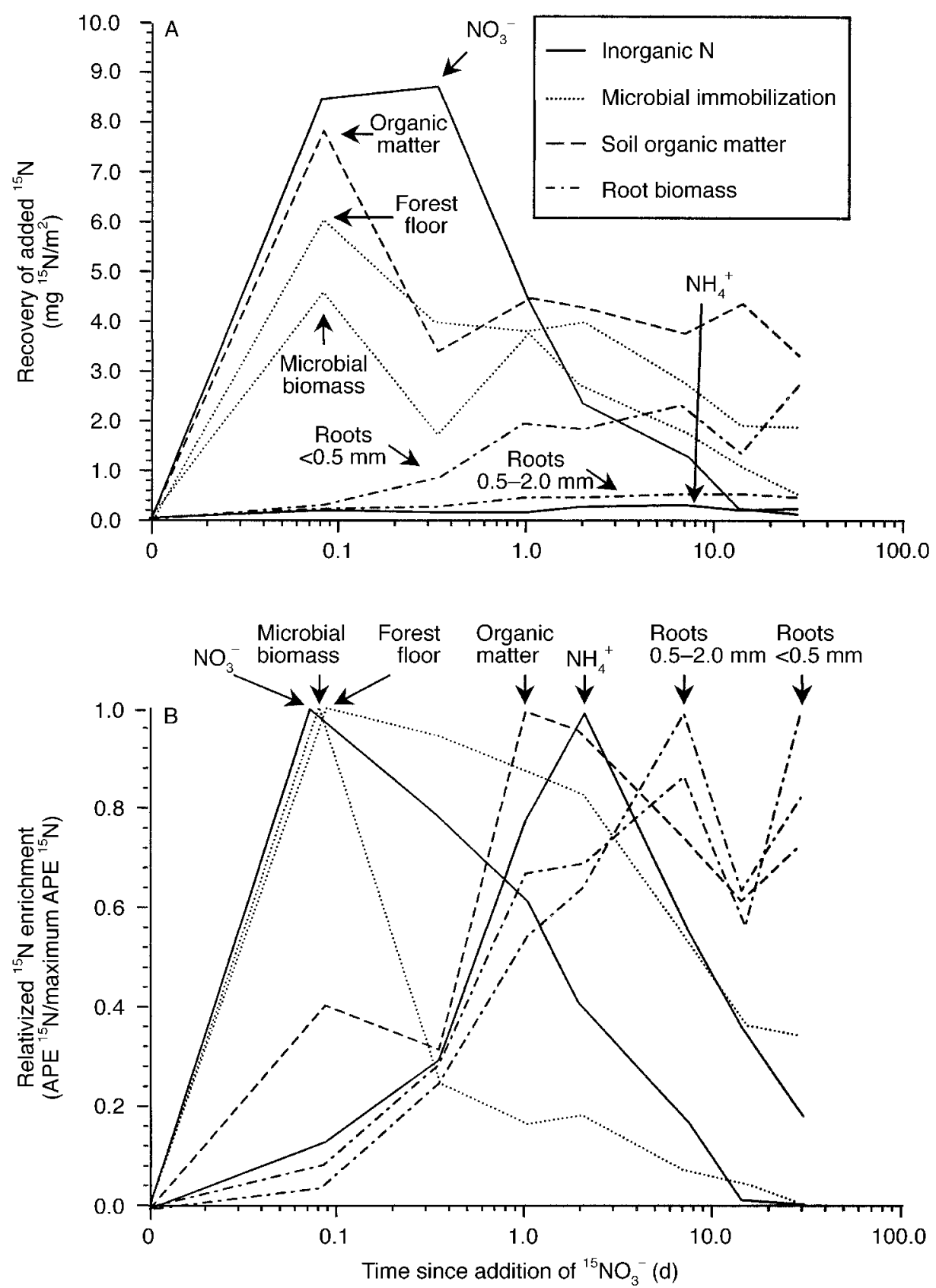

FIG. 2. The short-term fate (A) and flow (B) of added ${ }^{15} \mathrm{NO}_{3}{ }^{-}$in inorganic-N, microbial, soil-organic-matter and rootbiomass pools. Note that the time since addition of ${ }^{15} \mathrm{NO}_{3}{ }^{-}$is plotted on a logarithmic scale $\left(x\right.$-axis). (A) The fate of $\mathrm{NO}_{3}{ }^{-}$ additions was determined by estimating the recovery of added ${ }^{15} \mathrm{NO}_{3}{ }^{-}\left(29.5 \mathrm{mg}{ }^{15} \mathrm{~N} / \mathrm{m}^{2}\right)$ in a given pool as described in the Methods: Calculations and statistical analysis of the text. (B) The flow of $\mathrm{NO}_{3}{ }^{-}$among pools was ascertained by observing changes in the ${ }^{15} \mathrm{~N}$ enrichment of each pool over time; relativized ${ }^{15} \mathrm{~N}$ enrichments were calculated by dividing the atom $\%$ excess ${ }^{15} \mathrm{~N}\left(\mathrm{APE}{ }^{15} \mathrm{~N}\right)$ on each date (i.e., percentage ${ }^{15} \mathrm{~N}$ minus natural abundance, from Table 2) by the maximum APE ${ }^{15} \mathrm{~N}$ for each pool. See Methods: Calculations and statistical analysis for description of calculations.

may have initially leached from soil as $\mathrm{NO}_{3}^{-}$, which is very mobile in soil solution (as compared to $\mathrm{NH}_{4}^{+}$), or as dissolved organic nitrogen (DON) following cycling through microbial biomass. Leaching losses could be particularly great when soil water content is high. For example, total ${ }^{15} \mathrm{~N}$ recovery declined from $41 \%$ to
$31 \%$ during a 1 -wk period (day 7 to day 14 ) when $26 \%$ of the growing-season precipitation was deposited.

Although leaching may have contributed to the decline in ${ }^{15} \mathrm{~N}$ recovery over time, it is unlikely that leaching can account for all of the unrecovered ${ }^{15} \mathrm{~N}$ in our experiment. For example, we observed a large decline 
in the recovery of ${ }^{15} \mathrm{~N}$ during the first week of the experiment (from $93 \%$ to $41 \%$ ), a period during which $<1 \%$ of growing season precipitation fell and leaching losses were presumably minimal. Furthermore, data from another $\mathrm{NO}_{3}{ }^{-}$-addition experiment conducted in the same forests, in which much larger amounts of $\mathrm{NO}_{3}{ }^{-}$were applied $\left(30 \mathrm{~kg} \mathrm{~N} \cdot \mathrm{ha}^{-1} \cdot \mathrm{yr}^{-1}\right)$, indicate that $<46 \%$ of added $\mathrm{N}$ is annually lost to $\mathrm{NO}_{3}{ }^{-}$and DON leaching (K.S. Pregitzer, unpublished data). We suggest that plant uptake could account for much of the ${ }^{15} \mathrm{~N}$ that we were unable to recover. We have recently initiated a large-scale ecosystem ${ }^{15} \mathrm{~N}$-labeling experiment to address the issue of the long-term fate of anthropogenic $\mathrm{NO}_{3}{ }^{-}$.

Assuming that the decline in ${ }^{15} \mathrm{~N}$ recovery over the course of the entire experiment (i.e., from $93 \%$ at $2 \mathrm{~h}$ to $18 \%$ at $4 \mathrm{mo}$ ) is due to leaching and plant uptake, and that $<46 \%$ of the added label was lost due to leaching, we estimate that $29 \%$ or more of the added ${ }^{15} \mathrm{~N}$ could have been assimilated by plants. Results from several other studies indicate that forest trees can be major sinks for $\mathrm{N}$, taking up $11-57 \%$ of experimental ${ }^{15} \mathrm{NO}_{3}{ }^{-}$additions (Melin et al. 1983, Nadelhoffer et al. 1995, Buchman et al. 1996, Seely and Lajtha 1997). We did not estimate ${ }^{15} \mathrm{~N}$ recovery in stems, branches, or leaves, in our experiment, because quantifying the amount of label assimilated by overstory trees requires the addition of isotope over areas of forest much larger than the $9-\mathrm{m}^{2}$ plots used in our experiment. Nonetheless, the appearance of the ${ }^{15} \mathrm{~N}$ in tree roots in our study clearly indicates that plants were assimilating some of the added ${ }^{15} \mathrm{~N}$. Roots were initially a minor sink for ${ }^{15} \mathrm{NO}_{3}^{-}$(i.e., $<1 \%$ of the added label at $2 \mathrm{~h}$ ); however, ${ }^{15} \mathrm{~N}$ recovery in roots significantly increased $1 \mathrm{~d}$ following isotope additions and remained relatively high for the remainder of the growing season (6-9\%). If $\mathrm{N}$ assimilation by roots reflects incorporation into aboveground tissues, then our results suggest that plants could be an important sink for $\mathrm{NO}_{3}{ }^{-}$additions. Moreover, it appears that plant uptake may be an important fate for $\mathrm{NO}_{3}{ }^{-}$only after it has been metabolized by microorganisms.

\section{Flow of ${ }^{15} \mathrm{NO}_{3}-$}

Our data indicate that much of the ${ }^{15} \mathrm{NO}_{3}{ }^{-}$cycled rapidly through microorganisms before appearing in soil organic matter and plant roots. Although recovery of ${ }^{15} \mathrm{~N}$ fluctuated following addition of the label, after 4 wk there was little change in the recovery of ${ }^{15} \mathrm{~N}$ within a given pool (Fig. 1), suggesting that major $\mathrm{N}$ transfers occurred within the first $28 \mathrm{~d}$ of the experiment. Given that plant, microbial, and soil N pools (i.e., in milligrams $\mathrm{N}$ per square meter) varied little during this period, we used the change in their ${ }^{15} \mathrm{~N}$ enrichment to trace the flow of the isotope (Fig. 2B). For example, an increase in the ${ }^{15} \mathrm{~N}$ enrichment of a given pool over time indicates greater incorporation of the labeled $\mathrm{N}$ into that pool. In contrast, a decrease in ${ }^{15} \mathrm{~N}$ enrichment reflects a dilution of the percentage ${ }^{15} \mathrm{~N}$ due to an influx of ${ }^{14} \mathrm{~N}$ (assuming limited effects of isotopic discrimination on $\mathrm{N}$ transfers among pools over time steps of hours to days in our study). We suggest that the point at which maximal enrichment for a given pool occurs (i.e., greatest atom $\%$ excess ${ }^{15} \mathrm{~N}$ ) is an index of when ${ }^{15} \mathrm{~N}$ flow is greatest into that pool, and thus can be used to follow the flow of ${ }^{15} \mathrm{~N}$ among microorganisms, soil organic matter, and plants.

Initially, microorganisms appeared to out-compete plant roots for ${ }^{15} \mathrm{NO}_{3}{ }^{-}$. We found that the ${ }^{15} \mathrm{~N}$ enrichment of the forest floor and soil microbial biomass exhibited a significant increase immediately following ${ }^{15} \mathrm{NO}_{3}{ }^{-}$addition (i.e., at $2 \mathrm{~h}$, Fig. $2 \mathrm{~B}$ ). Because this was coincident with the peak in the ${ }^{15} \mathrm{~N}$ enrichment of $\mathrm{NO}_{3}{ }^{-}$ in soil solution, we conclude that there was significant microbial assimilation of $\mathrm{NO}_{3}{ }^{-}$. In contrast, the ${ }^{15} \mathrm{~N}$ enrichment of root biomass (fine roots and very fine roots) did not significantly increase until $1 \mathrm{~d}$ later and reached maximum levels on days 7 and 28 (Table 2, Fig. 2B). We also found that ${ }^{15} \mathrm{~N}$ recovery in forest floor and soil microbial biomass during the first $2 \mathrm{~d}$ of the experiment was significantly greater than recovery in very fine and fine root biomass (Fig. 2A), suggesting that microbial immobilization was the largest, immediate sink for anthropogenic $\mathrm{NO}_{3}{ }^{-}$. Even though we did not quantify ${ }^{15} \mathrm{~N}$ recovery in aboveground plant tissues, the much higher rates of $\mathrm{NO}_{3}{ }^{-}$uptake for microorganisms than for plants (compare initial slopes for forest floor and soil microbial biomass with roots, Fig. 2A) further indicate that microorganisms were better competitors for $\mathrm{NO}_{3}^{-}$.

Although it is has often been assumed that heterotrophic microorganisms have only a limited capacity for $\mathrm{NO}_{3}{ }^{-}$uptake (Rice and Tiedje 1989, Drury et al. 1991), microbial assimilation of $\mathrm{NO}_{3}{ }^{-}$can be significant in microsites where $\mathrm{NH}_{4}{ }^{+}$is absent (Schimel and Firestone 1989, Davidson et al. 1990). For example, high $\mathrm{NO}_{3}{ }^{-}$immobilization rates have been previously reported for soils in other mature forests (Zak et al. 1990, Davidson et al. 1992, Stark and Hart 1997). However, in those studies tree roots were excluded, making it difficult to determine the relative importance of $\mathrm{NO}_{3}{ }^{-}$ uptake by roots and microorganisms. In the presence of roots, several studies have demonstrated greater $\mathrm{NO}_{3}{ }^{-}$uptake by soil microorganisms than by herbaceous plants (Davidson et al. 1990, Zak et al. 1990, Groffman et al. 1993). Our results indicate that microorganisms out-compete tree roots for $\mathrm{NO}_{3}{ }^{-}$in an intact plant-soil system.

Some of the ${ }^{15} \mathrm{~N}$ initially assimilated by microorganisms as $\mathrm{NO}_{3}{ }^{-}$likely entered the soil-organic-matter pool following cell death. Estimates of microbial turnover from previous studies of forest soils range from 7 to 425 d (Davidson et al. 1992, Hart et al. 1994, Holmes and Zak 1999). We did not directly measure turnover rates of microbial ${ }^{15} \mathrm{~N}$ in our study, but the ${ }^{15} \mathrm{~N}$ recovery in both soil microbial biomass and the 
forest floor declined significantly within the first $10 \mathrm{~d}$ of the experiment (Fig. 2A), suggesting rapid movement of immobilized ${ }^{15} \mathrm{~N}$ through these pools. Similarly, Seely and Lajtha (1997) concluded that a significant portion of $\mathrm{NO}_{3}^{-}$additions in pine and mixedhardwood forests cycled through microbial pools within 2-7 d. Additional evidence for turnover of the ${ }^{15} \mathrm{NO}_{3}{ }^{-}$ initially immobilized by microorganisms comes from the observation that the maximal ${ }^{15} \mathrm{~N}$ enrichment of soil organic matter (day 1) occurred following peaks in the ${ }^{15} \mathrm{~N}$ enrichment of forest floor and soil microbial biomass (Fig. 2B). Although some ${ }^{15} \mathrm{~N}$ likely became stabilized in soil organic matter following microbial assimilation and turnover, the gradual decline in total ${ }^{15} \mathrm{~N}$ recovery in the soil-organic-matter pool (after relatively large recoveries immediately following addition of the label), suggests rapid flow of ${ }^{15} \mathrm{~N}$ through this pool as well.

In our study, some of the ${ }^{15} \mathrm{~N}$ cycling through microorganisms and soil organic matter appeared to be mineralized as $\mathrm{NH}_{4}{ }^{+}$and subsequently taken up by plants. Despite the fact that the total amount of ${ }^{15} \mathrm{~N}$ recovered in $\mathrm{NH}_{4}{ }^{+}$was never great, the added isotope clearly was present as $\mathrm{NH}_{4}{ }^{+}$(Fig. 2A). The low amount of ${ }^{15} \mathrm{~N}$ recovered as $\mathrm{NH}_{4}{ }^{+}$in our study does not necessarily reflect the importance of this pool as a pathway for the added ${ }^{15} \mathrm{~N}$, just as the pool size of $\mathrm{NH}_{4}{ }^{+}$(or $\mathrm{NO}_{3}{ }^{-}$) is a poor indicator of gross $\mathrm{N}$ flux and turnover rates (Davidson et al. 1990, Davidson et al. 1991). We argue that significant increases in the atom \% excess ${ }^{15} \mathrm{~N}$ of $\mathrm{NH}_{4}^{+}$between day 1 and day 7 indicate rapid flow of ${ }^{15} \mathrm{~N}$ through this pool (Fig. 2B, Table 1). In addition, the ${ }^{15} \mathrm{~N}$ enrichment of fine roots and very fine roots increased rather slowly and only reached maximal values (at day 7 or day 28) following a significant increase in the enrichment of $\mathrm{NH}_{4}{ }^{+}$, suggesting that roots took up and assimilated ${ }^{15} \mathrm{NH}_{4}{ }^{+}$. This result is similar to previous findings by Rothstein et al. (1996), who observed a greater potential for $\mathrm{NH}_{4}{ }^{+}$uptake than $\mathrm{NO}_{3}{ }^{-}$uptake in sugar maple and is consistent with the idea that late-successional species are better adapted to $\mathrm{NH}_{4}{ }^{+}$-based economies (Kronzucker et al. 1997).

Our results demonstrate the dynamic nature of $\mathrm{NO}_{3}$ cycling within this forest, as well as the importance of microorganisms as a pathway for anthropogenic- $\mathrm{NO}_{3}{ }^{-}$ retention. Immobilization into soil microbial biomass and the forest floor was the immediate but short-term sink for added ${ }^{15} \mathrm{NO}_{3}{ }^{-}$. Subsequently, the rapid cycling of $\mathrm{NO}_{3}{ }^{-}$through microorganisms, following cell death and turnover, facilitated $\mathrm{N}$ incorporation into more stable, long-term sinks. Although the ultimate fate of anthropogenic $\mathrm{NO}_{3}{ }^{-}$additions to this northern hardwood forest is likely in soil organic matter or plants, microbial immobilization is a major factor influencing the movement of $\mathrm{NO}_{3}{ }^{-}$among belowground $\mathrm{N}$ pools, and thus has the potential to influence long-term patterns of $\mathrm{N}$ retention.

\section{ACKNOWLEDGMENTS}

We thank Jared DeForest, Matt Dickinson, Rick Foster, Dawn Majewski, and Jen Maziasz for help in the field and laboratory. Eric Davidson, Peter Groffman, and an anonymous reviewer provided helpful comments on an earlier draft of this manuscript. The University of Michigan Biological Station provided laboratory facilities. This research was supported by a grant from the National Science Foundation (DEB 9629842).

\section{Literature Cited}

Aber, J. D. 1992. Nitrogen cycling and nitrogen saturation in temperate forest ecosystems. Trends in Ecology and Evolution 7:220-224.

Aber, J. D., K. J. Nadelhoffer, P. Steudler, and J. M. Melillo. 1989. Nitrogen saturation in northern forest ecosystems. BioScience 39:378-386.

Ågren, G. I., and E. Bosatta. 1988. Nitrogen saturation of terrestrial ecosystems. Environmental Pollution 54:185197.

Brookes, P. C., A. Landman, G. Pruden, and D. S. Jenkinson. 1985. Chloroform fumigation and the release of soil nitrogen: a rapid direct extraction method to determine microbial biomass nitrogen in soil. Soil Biology and Biochemistry 17:837-842.

Brooks, P. D., J. M. Stark, B. B. McInteer, and T. Preston. 1989. Diffusion methods to prepare soil extracts for automated nitrogen-15 analysis. Soil Science Society America Journal 53:1707-1711.

Buchman, N., G. Gebauer, and E. D. Schulze. 1996. Partitioning of N-15-labeled ammonium and nitrate among soil, litter, below- and above-ground biomass of trees and understory in a 15-year-old Picea abies plantation. Biogeochemistry 33:1-23.

Davidson, E. A., S. C. Hart, and M. K. Firestone. 1992. Internal cycling of nitrate in soils of a mature coniferous forest. Ecology 73:1148-1156.

Davidson, E. A., S. C. Hart, C. A. Shanks, and M. K. Firestone. 1991. Measuring gross nitrogen mineralization, immobilization, and nitrification by $\mathrm{N}-15$ isotopic pool dilution in intact soil cores. Journal of Soil Science 42:335349.

Davidson, E. A., J. M. Stark, and M. K. Firestone. 1990. Microbial production and consumption of nitrate in an annual grassland. Ecology 71:1968-1975.

Driscoll, C. T., and R. VanDresen. 1993. Seasonal and longterm temporal patterns in the chemistry of Adirondack lakes. Water, Air, and Soil Pollution 67:319-344.

Drury, C. F., R. P. Voroney, and E. G. Beauchamp. 1991. Availability of $\mathrm{NH}_{4}{ }^{+}-\mathrm{N}$ to microorganisms and the soil internal N-cycle. Soil Biology and Biochemistry 23:165-169.

Groffman, P. M., D. R. Zak, S. Christensen, A. Mosier, and J. M. Tiedje. 1993. Early spring nitrogen dynamics in a temperate forest landscape. Ecology 74:1579-1585.

Hart, S. C., G. E. Nason, D. D. Myrold, and D. A. Perry. 1994. Dynamics of gross nitrogen transformations in an old-growth forest: the carbon connection. Ecology 75:880891.

Holmes, W. E., and D. R. Zak. 1994. Soil microbial biomass dynamics and net nitrogen mineralization in northern hardwood ecosystems. Soil Science Society of America Journal 58:238-243.

Holmes, W. E., and D. R. Zak. 1999. Soil microbial control of nitrogen loss following clear-cut harvest in northern hardwood ecosystems. Ecological Applications 9:202-215.

Jackson, L. E., D. S. Schimel, and M. K. Firestone. 1989. Short-term partitioning of ammonium and nitrate between plants and microbes in an annual grassland. Soil Biology and Biochemistry 21:409-415. 
Johnson, D. W. 1992. Nitrogen-retention in forest soils. Journal of Environmental Quality 21:1-12.

Johnson, D. W., H. VanMiegroet, S. E. Lindberg, D. E. Todd, and R. B. Harrison. 1991. Nutrient cycling in red spruce forests of the Great Smoky Mountains. Canadian Journal of Forest Research 21:769-787.

Kronzucker, H. J., M. Y. Siddiqi, and A. D. M. Glass. 1997. Conifer root discrimination against soil nitrate and the ecology of forest succession. Nature 385:59-61.

Lovett, G. M., and J. D. Kinsman. 1990. Atmospheric pollutant deposition to high-elevation ecosystems. Atmospheric Environment: Part A-General Topics 24:2767-2786.

MacDonald, N. W., A. J. Burton, M. F. Jurgensen, J. W. McLaughlin, and G. D. Mroz. 1991. Variation in forest soil properties along a Great Lakes air pollution gradient. Soil Science Society of America Journal 55:1709-1715.

MacDonald, N. W., A. J. Burton, H. O. Liechty, J. A. Witter, K. S. Pregitzer, G. D. Mroz, and D. D. Richter. 1992. Ion leaching in forest ecosystems along a Great Lakes air pollution gradient. Journal of Environmental Quality 21:614623.

Magill, A. H., J. D. Aber, J. J. Hendricks, R. D. Bowden, J. M. Melillo, and P. A. Steudler. 1997. Biogeochemical response of forest ecosystems to simulated chronic nitrogen deposition. Ecological Applications 7:402-415.

Melin, J., H. Nommik, U. Lohm, and J. Flower-Ellis. 1983. Fertilizer nitrogen budget in a Scots pine ecosystem attained by using root-isolated plots and ${ }^{15} \mathrm{~N}$ tracer technique. Plant and Soil 74:249-263.

Merrill, A. G., and D. R. Zak. 1992. Factors controlling denitrification rates in upland and swamp forests. Canadian Journal of Forest Research 22:1597-1604.

Nadelhoffer, K. J., M. R. Downs, B. Fry, J. D. Aber, A. H. Magill, and J. M. Melillo. 1995. The fate of N-15-labelled nitrate additions to a northern hardwood forest in eastern Maine, USA. Oecologia 103:292-301.

NOAA (National Oceanic and Atmospheric Administration). 1983. Climate normals for the U.S. (Base: 1951-1980). Gale Research Company, Detroit, Michigan, USA.

Norton, J. M., and M. K. Firestone. 1996. N dynamics in the rhizosphere of Pinus ponderosa seedlings. Soil Biology \& Biochemistry 28:351-362.

Ollinger, S. V., J. D. Aber, G. M. Lovett, S. E. Millham, R. G. Lathrop, and J. M. Ellis. 1993. A spatial model of atmospheric deposition for the northeastern United States. Ecological Applications 3:459-472.

Pregitzer, K. S., A. J. Burton, G. D. Mroz, H. O. Liechty, and N. W. MacDonald. 1992. Foliar sulfur and nitrogen along an $800-\mathrm{km}$ pollution gradient. Canadian Journal of Forest Research 22:1761-1769.

Rastetter, E. B., M. G. Ryan, G. R. Shaver, J. M. Melillo, K. J. Nadelhoffer, J. E. Hobbie, and J. D. Aber. 1991. A general biogeochemical model describing the responses of the $\mathrm{C}$-cycle and $\mathrm{N}$-cycle in terrestrial ecosystems to changes in $\mathrm{CO}_{2}$, climate, and $\mathrm{N}$-deposition. Tree Physiology 9:101126

Rice, C. W., and J. M. Tiedje. 1989. Regulation of nitrate assimilation by ammonium in soils and in isolated soilmicroorganisms. Soil Biology and Biochemistry 21:597602.

Rothstein, D. E., D. R. Zak, and K. S. Pregitzer. 1996. Nitrate deposition in northern hardwood forests and the nitrogen metabolism of Acer saccharum Marsh. Oecologia 108:338344

Schimel, D. S., and M. K. Firestone. 1989. Nitrogen incorporation and flow through a coniferous forest soil profile. Soil Science Society of America Journal 53:779-784.

Seely, B., and K. Lajtha. 1997. Application of a ${ }^{15} \mathrm{~N}$ tracer to simulate and track the fate of atmospherically deposited $\mathrm{N}$ in the coastal forests of the Waquoit Bay Watershed, Cape Cod, Massachusetts. Oecologia 112:393-402.

Shannon, J. D., and D. L. Sisterson. 1992. Estimation of S-n and NOx-n deposition budgets for the United States and Canada. Water, Air, and Soil Pollution 63:211-235.

Stark, J. M., and S. C. Hart. 1997. High rates of nitrification and nitrate turnover in undisturbed coniferous forests. Nature 385:61-64.

Strickland, T. C., P. Sollins, N. Rudd, and D. S. Schimel. 1992. Rapid stabilization and mobilization of N-15 in forest and range soils. Soil Biology and Biochemistry 24:849855.

Vitousek, P. M., J. D. Aber, R. W. Howarth, G. E. Likens, P. A. Matson, D. W. Schindler, W. H. Schlesinger, and D. G. Tilman. 1997. Human alteration of the global nitrogen cycle: sources and consequences. Ecological Applications 7: 737-750.

Vitousek, P. M., and P. A. Matson. 1985. Disturbance, nitrogen availability, and nitrogen losses in an intensively managed loblolly pine plantation. Ecology 66:1360-1376.

Wilkinson, L. 1993. SYSTAT: the system for statistics. SYSTAT, Evanston, Illinois, USA.

Zak, D. R., P. M. Groffman, K. S. Pregitzer, S. Christensen, and J. M. Tiedje. 1990. The vernal dam-plant microbe competition for nitrogen in northern hardwood forests. Ecology 71:651-656.

Zogg, G. P., D. R. Zak, A. J. Burton, and K. S. Pregitzer. 1996. Fine root respiration in northern hardwood forests in relation to temperature and nitrogen availability. Tree Physiology 16:719-725. 